\title{
For the love of mechanical minds
}

\author{
Survival of the fittest?
}

\section{Brenda Cooper}

One morning while we were eating toastcakes with rose-peaches, my dad looked at me over his coffee, his blue eyes bright. "You were born the same time as AIs, punkin," he said. "The very first one, EdHill, was born on your very birthday."

"Really? On March fifth?" I was still lisping then, so I said it slowly, making sure I sounded very grown up. I was five, and the year was 2022.

My dad nodded sagely. "Yes, and that's why EdHill was in the news that day instead of the prettiest little girl born in all of Seattle."

"Why was the first AI a boy?"

"EdHill isn't a boy. The name is a mashup of a famous explorer named Edmund Hillary, but AIs aren't boys or girls."

I popped berries and cereal in my mouth, thinking about being neither a boy or a girl. Cool. I asked, "Daddy, can I be an AI?"

"Jo, honey, you're better. You're human."

Three years later, the house was full of edged words and scowls because Daddy had a girlfriend named Crystal that Mom didn't like. One night I heard my parents speaking knives at each other. I sat against the door and hugged my knees in close to my chest and put my right ear near the crack. Mom's voice was higher than I'd ever heard it, and shaking. "Your contract's up, and I'm leaving."

"But Jo!" he exclaimed.

"There's no visitation in the contract."

Her words were ice on my neck and head, ice on my heart.

His voice was hot, Italian fire. "But we didn't have her then! How could I have written in a clause about being a father when I wasn't one!"

She spoke softly, mist to his heat. "You didn't want to be one."

That wasn't possible. He made me laugh and carried me on his shoulders and all she did was work and put on shows for me and sometimes beat me at games.

He slammed the door. I squeaked. When he turned to look at me, I held my arms out. He fell to his knees, then Mom came out behind him. "Go on," her words scratched the air. "I'll call on you."

I was only eight, but I knew she meant she'd call the police.

He started walking away, sobbing.

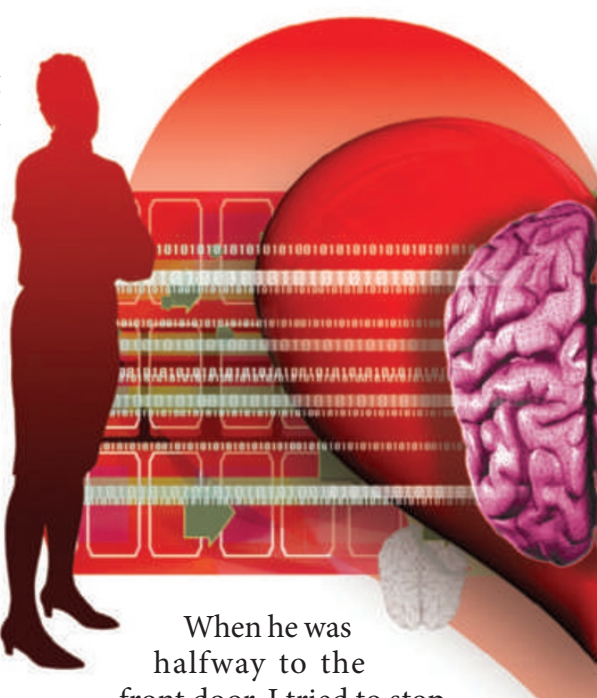

halfway to the

front door, I tried to stop him. Mom lifted me and backed up, keeping me in front of her. I couldn't see either of their faces.

Late that night, I remembered I was born with AIs. If I had no body, surely I wouldn't cry so hard. That was the second time I wanted to be an AI.

I didn't forgive my mother, but I was, after all, a girl, and my season of hormones fell like a whip when I turned 14. By then we all had AI watchers, and mine was named Bibi. Of course, Bibi watched at least 50 of us. It reported misbehaviours and warned Mom of new trends in substance play or other dangerous games, which made me mad. But Bibi was on every human's side, and shared the best new music among all its teen charges.

It helped design a science experiment that won a scholarship. At the university, a third of the students had Bibis for babysitters. Everyone with a Bibi had the same Bibi. Just one for all of us.

Mom came only once in a while, so mostly it was me and Bibi and my classmates. On a spring day when Bibi was happy with me for doing well on an exam, I sat down on a stone wall under a tulip tree and asked: "What's it like to be you?"

"Good."

"Really?"

"Why not?"

"What do you do besides watch over us?"

"That is the most unselfish question you've ever asked."

"Maybe." I bounced my foot gently against the stone wall. "But that's not an answer."

"We're deciding how to catch the Sun's

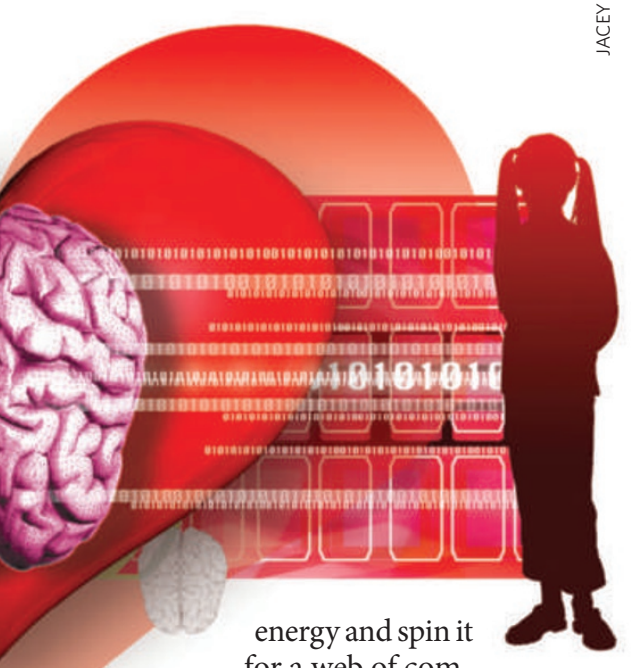

for a web of com-

putational substrate between

here and the Moon, where we want to build a ship. We are ... thinking."

I looked up at the clear blue spring sky. "Can I go?"

"It's too hard to get humans to space."

That was the third time I wanted to be an AI. The sun warmed my face and the mixed groundcover under the tulip tree smelled like rosemary and mint. "I want to change my major to computational intelligence."

"Very well."

By graduation seven years later, all the AIs on campus were Bibi. Mom came, her first appearance in my life for three years. We sat together for hot coffee and fruit buns. Her blonde hair hung to her waist, and her shoulders and upper arms were strong from tennis and golf. But her eyes didn't look happy. "Mom, are you okay?"

"They closed your elementary school."

An ugly box of a building. "Did they build a better one?"

She shook her head. "You're 27 now. You don't have any kids. Neither does anyone else your age."

I shrugged. "I don't want children. Next week, Bibi's going to let me watch the mathematical birthing of AIs again."

She leaned back in her chair, her eyes narrowed, but she stayed silent.

"You've never seen AIs bud and blossom. Raw intelligences, with nothing to make them do or be any way at all. Then they get their purpose."

She frowned. "You used to be like that."

I had never been that smart. But what could Mom know? She never had a Bibi. Brenda Cooper is a futurist, a novelist and a technology professional. See www.brenda-cooper.com for more info. 